\title{
Brachial artery thrombosis mimicking De Quervain's syndrome: a case report
}

\author{
Mehmet Ağırman, ${ }^{1}$ Sena Tolu, ${ }^{1}$ Özdil Başkan, ${ }^{2}$ Işl Üstün ${ }^{3}$ \\ ${ }^{1}$ Department of Physical Medicine and Rehabilitation, İstanbul Medipol University, İstanbul, Turkey \\ ${ }^{2}$ Department of Radiology, İstanbul Medipol University, İstanbul, Turkey \\ ${ }^{3}$ Department of Physical Medicine and Rehabilitation, Bağcllar Training and Research Hospital, İstanbul, Turkey \\ Received: August 2015 Accepted: November 2015
}

\begin{abstract}
Upper limb occlusions are rare and the clinical presentation may vary depending on the affected arteries. A detailed history and physical examination may reveal possible causes and can facilitate the differential diagnosis. It can be misdiagnosed as musculoskeletal diseases due to similar clinical manifestations. In this report, we present a case with wrist pain mimicking de Quervain's syndrome diagnosed as subacute brachial artery thrombosis due to factor II gene mutation. In conclusion, physicians should be cautious to avoid unnecessary delay in the diagnosis of thrombosis in young patients.
\end{abstract}

Keywords: De Quervain disease; thrombosis; wrist.

Arterial thromboses may occur due to genetic, environmental, and individual risk factors. Patients usually present with pain, pulselessness, paresthesia, paralysis, polar and pallor (6 P's). The clinical presentation may vary depending on the affected arteries. The duration and severity of an arterial occlusion can cause serious complications; therefore, prompt diagnosis is critical. Arterial thromboses of the upper limb are rare, with the most common causes being embolism and trauma. ${ }^{[1]}$ A detailed history and physical examination may reveal possible causes and can facilitate the differential diagnosis.

Herein, we report a case presenting with wrist pain mimicking de Quervain's syndrome diagnosed as subacute brachial artery thrombosis due to factor II gene mutation.

\section{CASE REPORT}

A 31-year-old female patient was admitted to our clinic with left wrist pain over the thumb side. The symptoms appeared spontaneously two weeks earlier and increased while using the hand. In her detailed history, the patient had no complaint of numbness or paresthesia. She received an oral contraceptive (drospirenone ethinyl estradiol) for four years due to polycystic ovary syndrome and she was a non-smoker. In the initial physical examination, there was pain on palpation of the extensor tendons of the left wrist with positive Finkelstein's test result. Peripheral pulses were palpable, and sensory and motor examinations were normal. According to these findings, she was treated for de Quervain's tenosynovitis with a nonsteroidal anti-inflammatory medication, cooling, and a splint which immobilized the wrist and thumb. At one week of follow-up, pain was slightly reduced, while symptoms of pallor, weakness, and coldness appeared. Her physical examination indicated that the left hand was mildly hypothermic, and the left radial artery pulse was reduced by holding up the arm. Cervical radiography revealed normal findings. Venous and arterial Doppler ultrasonography (USG) was performed. Doppler USG of the brachial artery demonstrated thrombi in the final section of the brachial artery and in the proximal segments of both the radial and ulnar arteries. Computed tomography showed that the left distal brachial artery and the proximal part of the radial and ulnar arteries were

Corresponding author: Mehmet Ağırman, MD. İstanbul Medipol Üniversitesi Tıp Fakültesi, Fiziksel Tıp ve Rehabilitasyon Anabilim Dalı, 3420 Bağclar, İstanbul,

Turkey. e-mail: mehmetagirman@yahoo.com 

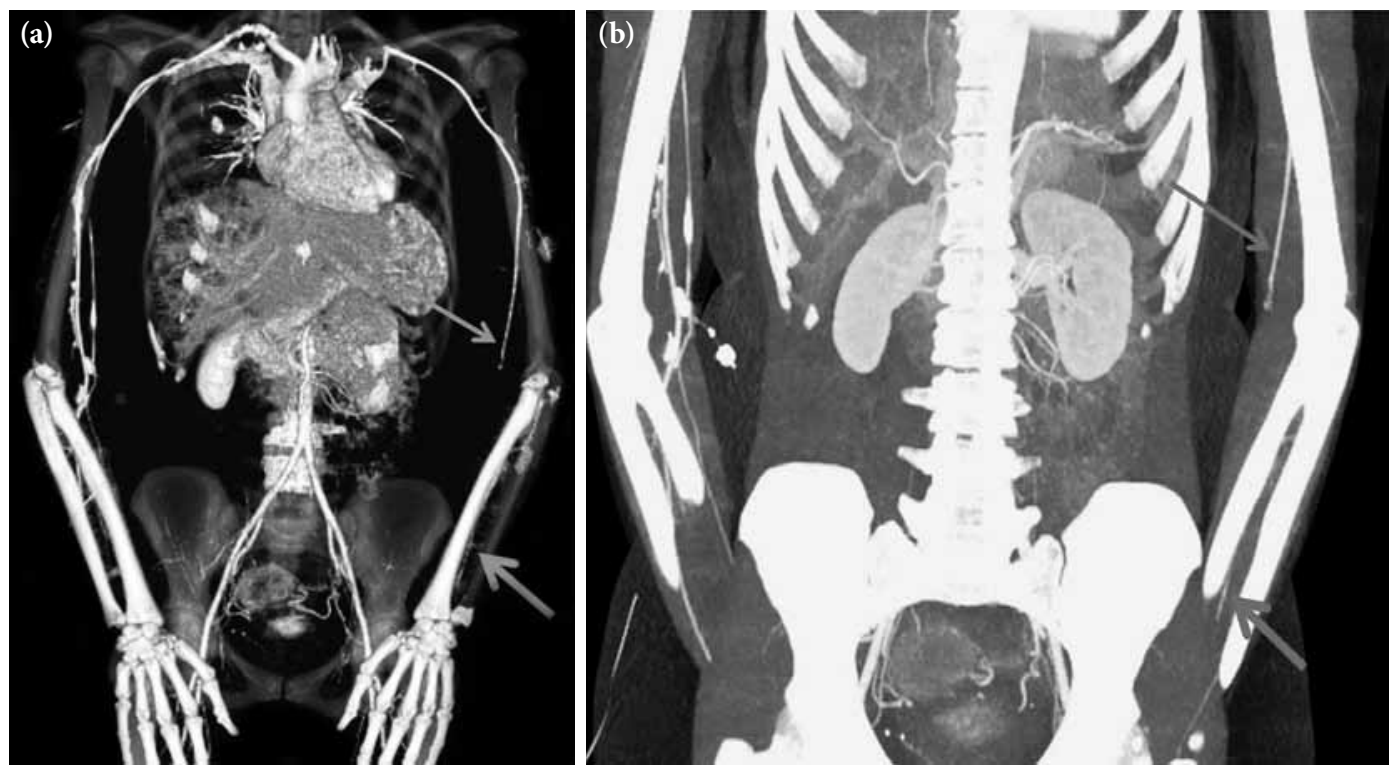

Figure 1. (a) A MIP image. (b) Three-dimensional MIP image. The distal parts of the right brachial artery and the right radial artery were occluded (long arrow). Lumen of the ulnar artery can be seen distally (short arrow). MIP: Maximum intensity projection.

obstructed, whereas a short segment of the ulnar artery was re-canalized (Figure 1). These findings were consistent with obstructive changes. The laboratory test results, including anti-phospholipid antibodies, D-dimer, anti-cardiolipin antibodies, homocysteine, protein $\mathrm{C}$, protein $\mathrm{S}$, and factor $\mathrm{V}$ Leiden mutation, were normal. In addition, cardiac examination findings were normal. However, the patient was found to have a heterozygous prothrombin G20210A (factor II) mutation. A written informed consent was obtained from the patient.

The oral contraceptive medication was discontinued, and she was treated using anticoagulant therapy and low-molecular-weight heparin for two months. Following treatment, she reported pain relief. At two months of follow-up, she was still pain-free, and total resolution of thrombus was detected in repeated arterial Doppler USG.

\section{DISCUSSION}

Many conditions may lead to a thrombosis in the peripheral arteries. Brachial artery catheterization injury is the most common cause of direct arterial injury. ${ }^{[1]}$ Trauma, atherosclerotic plaque thrombosis, external compression, hypercoagulable states, and oral contraceptives are other reasons of ischemia. ${ }^{[1,2]}$ In contrast to lower limb arterial occlusions, upper limb occlusions are rare, and few studies have been published until now. Patients usually suffer from sudden-onset pain, which can radiate to the forearm, elbow, and wrist, depending on the duration and location of the blockage. In case of delay, the risk of amputation and residual functional impairment risk has been reported to be $8 \%{ }^{[3]}$

Our case initially suffered from pain alone without any other signs of ischemia. Due to normal peripheral pulses, normal arm coloration, and tenderness of the wrist extensor tendons, de Quervain's syndrome was initially suspected. At one week of follow-up, as she suffered from radiating pain to the elbow, and pallor and coldness symptoms, arterial Doppler USG was performed to further investigate an arterial thrombosis.

In her medical history, there were two risk factors for an arterial thrombosis: drospirenone-containing oral contraceptive use and the prothrombin G20210A mutation. These factors could have led to an arterial thrombosis. Although several studies on these factors have been published to date, this is, to the best of our knowledge, the first case of a peripheral arterial thrombosis.

The association between prothrombin G20210A and arterial events is still controversial. Previous studies have shown that this mutation is strongly associated with spontaneous and recurrent venous thromboembolism. ${ }^{[4,5]}$ Several studies demonstrated 
that the prothrombin gene mutation had no effect on arterial thrombosis, ${ }^{[6-9]}$ although some authors suggested that the prothrombin G20210A mutation was weakly associated with some arterial thrombosis ${ }^{[4,10,11]}$ Mueller et al. ${ }^{[12]}$ found no relationship between the prothrombin G20210A mutation and chronic peripheral arterial disease, although this mutation may play a role in the development of acute thrombosis. ${ }^{[12]}$

The acute onset of symptoms in the presented case supported this hypothesis. Another confounding factor was the previous four-year use of oral contraceptives. Several studies demonstrated an increased risk of venous thrombosis in women using drospirenonecontaining oral contraceptives. ${ }^{[1]}$ However, the effect on the arterial thrombosis still remains unclear. An increased risk of arterial thrombosis was also reported, ${ }^{[3,1]}$ whereas some others showed a protective effect. ${ }^{[13]}$ Lidegaard et al. ${ }^{[14]}$ compared the arterial thrombotic risk in users with non-users of drospirenone-containing contraceptives, and concluded that these contraceptives were associated with an increased risk of stroke and myocardial infarction.

Furthermore, symptoms of our case were initially suggestive of de Quervain's syndrome. However, during follow-up, ischemia symptoms appeared; therefore, further investigations were needed to establish a definite diagnosis.

In conclusion, upper limb peripheral-artery thromboses may present as musculoskeletal pain. Herein, we present a case to highlight the importance of definite diagnosis in a patient with a subacute brachial artery thrombosis mimicking de Quervain's syndrome. Therefore, physicians should be cautious to avoid an unnecessary delay in the diagnosis of thrombosis in young patients.

\section{Declaration of conflicting interests}

The authors declared no conflicts of interest with respect to the authorship and/or publication of this article.

\section{Funding}

The authors received no financial support for the research and/or authorship of this article.

\section{REFERENCES}

1. Coskun S, Soylu L, Coskun PK, Bayazit M. Short series of upper limb acute arterial occlusions in 4 different etiologies and review of literature. Am J Emerg Med 2013;31:1719.

2. Deguara J, Ali T, Modarai B, Burnand KG. Upper limb ischemia: 20 years experience from a single center. Vascular 2005;13:84-91.

3. Quraishy MS, Cawthorn SJ, Giddings AE. Critical ischaemia of the upper limb. J R Soc Med 1992;85:269-73.

4. Kim RJ, Becker RC. Association between factor V Leiden, prothrombin G20210A, and methylenetetrahydrofolate reductase $\mathrm{C677T}$ mutations and events of the arterial circulatory system: a meta-analysis of published studies. Am Heart J 2003;146:948-57.

5. Svensson PJ, Dahlbäck B. Resistance to activated protein C as a basis for venous thrombosis. N Engl J Med 1994;330:517-22.

6. Ozmen F, Ozmen MM, Ozalp N, Akar N. The prevalence of factor V (G1691A), MTHFR (C677T) and PT (G20210A) gene mutations in arterial thrombosis. Ulus Travma Acil Cerrahi Derg 2009;15:113-9.

7. Dönmez Y, Kanadasi M, Tanriverdi K, Demir M, Demirtas M, Cayli M, et al. Prothrombin 20210GA and factor V Leiden mutations in patients less than 55 years old with myocardial infarction. Jpn Heart J 2004;45:505-12.

8. Batioğlu F, Atmaca LS, Karabulut HG, Beyza Sayin D. Factor $\mathrm{V}$ Leiden and prothrombin gene G20210A mutations in ocular Behçet disease. Acta Ophthalmol Scand 2003;81:283-5.

9. Renner W, Köppel H, Brodmann M, Pabst E, Schallmoser K, Toplak H, et al. Factor II G20210A and factor V G1691A gene mutations and peripheral arterial occlusive disease. Thromb Haemost 2000;83:20-2.

10. Arruda VR, Annichino-Bizzacchi JM, Gonçalves MS, Costa FF. Prevalence of the prothrombin gene variant (nt20210A) in venous thrombosis and arterial disease. Thromb Haemost 1997;78:1430-3.

11. Sofi F, Lari B, Rogolino A, Marcucci R, Pratesi G, Dorigo $\mathrm{W}$, et al. Thrombophilic risk factors for symptomatic peripheral arterial disease. J Vasc Surg 2005;41:255-60.

12. Mueller T, Marschon R, Dieplinger B, Haidinger D, Gegenhuber A, Poelz W, et al. Factor V Leiden, prothrombin G20210A, and methylenetetrahydrofolate reductase C677T mutations are not associated with chronic limb ischemia: the Linz Peripheral Arterial Disease (LIPAD) study. J Vasc Surg 2005;41:808-15.

13. Wu CQ, Grandi SM, Filion KB, Abenhaim HA, Joseph L, Eisenberg MJ. Drospirenone-containing oral contraceptive pills and the risk of venous and arterial thrombosis: a systematic review. BJOG 2013;120:801-10.

14. Lidegaard Ø, Løkkegaard E, Jensen A, Skovlund CW, Keiding N. Thrombotic stroke and myocardial infarction with hormonal contraception. N Engl J Med2012;366:2257-66. 